\title{
INVESTIGATING INTRALINGUAL AND INTERLINGUAL ERRORS OF ALGERIAN MIDDLE SCHOOL EFL LEARNERS IN THEIR WRITTEN COMPOSITIONS: A CASE STUDY
}

\author{
Noria Ghezzou \\ Department of English \\ University of Annaba, Algeria \\ savoirle@live.fr
}

\author{
Sofiane Mammeri \\ Department of English \\ University of Annaba, Algeria \\ mammeriss@gmail.com
}

\begin{abstract}
The present paper investigates the intralingual and interlingual errors of Algerian Middle School EFL learners in their writing compositions. The purpose of the study is to identify the major errors and classify them according to their types and sources. Besides, it aims at suggesting some solutions to this problem. The sample of the study consists of $1 / 3$ of fourth year learners of Youcef Ben Berkane Middle School of Akbou - Bejaia, Algeria. Accordingly, a corpus of 62 written compositions is collected and analyzed qualitatively and quantitatively. The findings revealed that all the participants significantly make errors in their written compositions. Besides, most of the learners make errors at the levels of spelling, tense, punctuation, subject-verb agreement, sentence fragment, articles, prepositions, and French interference. In view of that, it is also shown that the main source of the learners' errors is intralingual followed by interlingual transfer. However, promoting extensive reading, integrating reliable writing activities in the classroom and practicing handwriting are some of pedagogical implications suggested to overcome the learners' repeated errors.
\end{abstract}

Key Words: EFL, Writing, Language Interference, Error Analysis, Bejaia, Algeria.

\section{INTRODUCTION}

Writing is a language skill that involves more sub-skills than any other educational activity. From the first grades to university, writing takes a prominent position in the learning process. As learners progress in their education, they are asked to work more in/with writing than in any other language skill. That is, learners tend to write daily and they are usually tested about their writings. Accordingly, middle school learners write about many 
subjects across the program; they write to communicate, notice, and resolve problems. At an advanced level, middle school learners become experienced and their writing starts to improve and even become better than their oral performance (Time4Writing, 2015). However, writing problems become abundantly visible which may affect the learners' progress. Hence, identifying common writing errors early and determining the main sources behind them; and then, suggesting some implications to overcome these errors are at the core concern of this study.

\section{Statement of the Problem}

As EFL teachers at Bejaia University, Algeria, we notice that our EFL learners face many problems in their written compositions. Many researchers (Kertous, 2013; Boulekroune, 2014; and Mammeri, 2015) found that Bejaia EFL students do not master satisfactorily writing. Based on the aforementioned situation, we do believe that a deep investigation of the EFL learners' writings should be considered at early grades (i.e., before coming to the University). Accordingly, we accept as true that this writing incompetence is rooted to the first years of English learning namely at the middle school. Hence, the main concern of the present study is to examine the intralingual and interlingual errors that may exist in the middle school learners' written compositions.

\section{Questions of the Study}

The present study attempts to answer the following research questions:

- What are the most frequent errors do middle school EFL learners make in their compositions?

- What are the sources of these errors?

- What can EFL teachers do to remediate these errors?

\section{Hypothesis of the Study}

The present researchers hypothesize that the written errors made by the middle school learners are mainly intralingual, with high frequency, and interlingual, with low frequency.

\section{THEORETICAL BACKGROUND}

Writing in a foreign language is a complex process which requires cognitive examination and linguistic combination especially for young learners. Besides, writing as a complex process makes it rather difficult. In view of that, Heydari \& Bagheri (2012:1583) state: "writing is a complex process even in the first language; undoubtedly, it is more complicated to 
write in a foreign language." Moreover, Kitzhaber (1963:59) claims that teaching young learners is frustrating and their errors are "time-consuming, and laborious' for teachers.

As a result, many researchers have classified writing difficulties according to different areas. Byrne (1988 - as cited in Ouskourt 2008: 15-16) looked at the problems in writing from psychological, linguistic and cognitive perspectives. First, psychologically, it is crucial to mention that what makes writing difficult is the fact that it is a personal and individual activity in which learners write on their own without any interaction or feedback from neither the teacher nor peers. Second, linguistically, the written form is completely led by the learner himself who should pay attention to the linguistic forms and respect the grammatical rules. Third, cognitively, when learners write they have to respect the standards of coherence and clarity throughout their texts.

\section{Error Analysis}

Appeared in the late 1960s and flourished in the 1970s, and as a result of the failure of Contrastive Analysis (CA) to adequately account for student errors, Error Analysis (EA) came as an alternative approach. According to Yang (2010: 266), error analysis is "the process of determining the incidence, nature, causes, and consequences of unsuccessful language". Additionally, EA provides data and results in actual and attested problems and not on hypothetical ones (Sridhar, 1975). EA has suggested a new way of looking at errors; they are no longer seen as 'sins' but as a way of making learning significant (Sridhar, 1975). Thus, Corder (1974 - as cited in Al-Bayati 2013:42) claims:

"The study of errors is part of the investigation of the process of language learning. It provided us with a picture of the linguistic development of the learner and may give indications to the learning strategies".

Also, EA is important in improving teaching methods. That is, it supplies valuable data that can be used in the preparation of teaching materials, textbooks, and assessments, as well as practical applications for language teachers. Corder (1973) suggested five steps to follow during error analysis namely collection of data, identification of errors, description of errors, explanation of errors, and evaluation of errors.

\section{Error Sources}

Naturally, errors are an expected part of the learners' production. Therefore, many scholars sought to find why are certain errors made. Richards (1974) classified error sources into three categories as follows: 
1 Interlingual Errors: they are errors that result from transfers from other languages. This reflects the inability of the learner to separate or distinguish between two different languages.

2 Intralingual Errors: according to Richards (1980 - as cited in Al-Khatib 2013:31), intralingual errors are "items produced by the learner which reflect not the structure of the mother tongue, but generalizations based on partial exposure to the target language". That is to say, errors related to incorrect generalization of target language rules. Moreover, Richards (1970) distinguished between four categories of intralingual errors namely, overgeneralization of rules, ignorance of rule restrictions, incomplete application of rules, and false concept hypothesized.

Developmental Errors: they are errors resulting from the learner's hypothesis about the target language rules relying on a limited background.

However, in the present study, we consider only the two first sources i.e., interlingual and intralingual.

\section{LITERATURE REVIEW}

Many studies have been conducted in the field of writing which have come widely to the same conclusion reporting that writing is a difficult task either for native or non-native learners. Similarly, in the Arab world, as it is reported in several studies (such as Abdul Haq, 1982; Al-Khuweileh \& AlShoumali, 2000; Al-Hazmi, 2006; and Al-Samadani, 2010), Arab students face a lot of problems in their writing in all language components namely spelling, vocabulary, grammar, and syntax. Hence, in what follows, the present researchers selected some reviewed studies to put the reader in the field of error analysis and to highlight in the last paragraph the contribution of the present investigation.

Taghavi (2012) examines errors in writing tasks of twenty Iranian lower intermediate male students aged between 13 and 15 . The main concern of the study is to find out the most frequent errors made by these learners during their process of learning languages. To reach the aim of the study, a subject was given to the participants to write a composition about the seasons of the year. After data collection and analysis, the results show that the most common errors are spelling, word choice, verb tense, preposition, subject-verb agreement, and word order. Moreover, the sources of errors are both interlingual and intralingual. Also, the participants have a relatively weak vocabulary and their sentences are sometimes incomprehensible.

Zawahreh (2012) investigates the errors in the English essays of the tenth grade learners in females and males schools in Ajloun, Jordan. The aim of the study is to identify the written errors made by the tenth grade, estimate the predominant errors, and explain the causes behind these errors. The sample of 
study consists of 350 learners from Ajloun schools. And, they were asked to write a full essay in English. The findings report that the most predominant errors among the tenth grade learners in Ajloun schools are as follows: lack of agreement between subject and the main verb, prepositions, omission of the main verb, and lexis.

Adway (2013) examines the errors of twelfth grade male learners in the use of definite and indefinite articles in the secondary schools at Umm Al Quwain Educational Zone. The purpose of the study is to find out the most frequent errors and their sources. Moreover, to suggest teaching and learning strategies to cope with the learners' challenges. The instruments of the study are the teachers' interviews and the learners' tests. The main finding of the study is that the main source of the learners' errors in using definite and indefinite articles in English is not language interference but rather intralingual. He adds that these errors could be reduced only with appropriate teaching strategies/methods.

Sawalmeh (2013) investigates the occurring errors in a corpus of 32 essays written by 32 Saudi male learners of English. Besides, all the participants are graduated from Saudi secondary schools and joined the preparatory program at the University of Ha'il. The aim of the study is to investigate the most common errors made by these learners and then to find out the reasons behind such instances. The main instrument of the study is the participants' written essays. The results show that the participants in this study made ten common errors which are: verb tense, word order, singular/plural form, subject-verb agreement, double negatives, spellings, capitalization, articles, sentence fragments and prepositions. Furthermore, Sawalmeh concluded that these errors are due to the learners' mother tongue negative transfer. Finally, the researcher suggests some pedagogical implications and helpful suggestions that may reduce such errors among Arab learners.

Javid and Umer (2014) study the areas of difficulty in academic writing, the factors behind these difficulties, and the corrective measures in the Saudi EFL context. The aim of the study is to identify the common difficulties in writing along with their sources and to suggest possible measurements to consider. Therefore, the researchers administered a 40-item questionnaire to 194 Saudi EFL learners (108 male and 86 female) studying at Taif university. The findings of the study show that Saudi EFL learners have serious problems in their academic writing reflected in their weaknesses in using appropriate lexical items, organisation of ideas, and grammar. Moreover, the other secondary areas include: wrong use of prepositions, spellings, irregular verbs, articles, punctuation, suffixes and prefixes. At the end, the researcher recommended the implementation of a rigorous admission policy, extensive language courses and activities, increasing practice in academic writing, and exploiting modern teaching techniques.

Mammeri (2015) examines the written compositions of Bejaia EFL students at the level of morphosyntax. The purpose of the study is to identify, 
classify, and supply a plausible interpretation for the different errors. The corpus of the study consists of 120 English written compositions of 120 EFL students enrolled in the English department of Bejaia University, Algeria. The findings of the study revealed eight morphosyntactic errors namely word order, subject-verb agreement, verb structure, noun/adjective/adverb structure, word/morpheme addition, word morpheme omission, short forms/abbreviations, and conversational informal words. Then, he concludes with some pedagogical implications for a better writing performance such as the adoption of the pertinent teaching procedure like the Presentation Practice, and Production (PPP), the collaboration between the teachers of writing and morphosyntax/grammar so that their syllabuses will complement each other, and the promotion of free reading and writing among EFL learners.

Hence, the present study agrees with the aforementioned reviewed studies in that it deals with EA in EFL learners' written compositions. Besides, it attempts to identify and categorize the errors according to their sources (i.e., intralingual and interlingual). However, it is different from the preceding ones in the following: it is a comprehensive study that attempts to identify all occurring errors in the middle school learners' written compositions. Moreover, the sample of the study consists of Kabyle EFL pupils studying French and English simultaneously at schools. Hence, interlangual errors are expected.

\section{METHODS}

To answer the questions and meet the aim of the present study, we opted for a mixed method consisting of both qualitative analysis and quantitative measurement of data. Hence, the corpus of the study consists of 62 written compositions (representing 30\% of the whole population). They are collected during the second semester of the academic year of 2014-2015. The analysis consists of identifying all the existing the errors and classifying them according to their categories and sources by presenting them in tables and figures.

\section{Purpose of the Study}

Generally, the present study aims at raising EFL learners' awareness of the importance of the writing skill in the learning of any language. Besides, it intends to facilitate the learning process for both learners and teachers. Moreover, the study attempts to draw the learners' attention to the different types of errors by exploring their difficulties and challenges in writing. Specifically, it attempts to collect, identify, and categorize the errors according to their types and sources. Finally, some pedagogical implications are addressed. 


\section{Population \& Sample of the Study}

The population of this study is fourth year pupils at Youcef Ben Barkene Middle School situated in Akbou, one of Bejaia's towns. The total number of fourth year learners is 189 distributed into 6 classes. However, only two classes are selected as our sample namely 4.AM 1 and 4.AM 3. These two classes are chosen to be under investigation using random sampling. Besides, the sample of the study consists of 62 female and male learners (representing $1 / 3$ of the whole population).

\section{Significance of the Study}

Although much research has been done on the field of error analysis in EFL learners' written compositions, still this topic is worth investigating with new populations and contexts. Hence, to the best knowledge of the present researchers, there is no EFL study that is conducted on the learners of Youcef Ben Berkane Middle School in Akbou, Bejaia. From this exclusivity, the present study can be considered as a significant input to EFL/ELT studies in Algeria. Besides, the importance of the study lies in its findings and implications that can be used by middle school teachers in order to improve their teaching practices and design effective activities for a better writing performance. Moreover, the present researchers believe that conducting such studies on young learners at early grades help assess and evaluate the EFL learning/teaching. Besides, they will prepare the young learners for higher education where they are expected to be good in all language skills.

\section{RESULTS \& DISCUSSION}

The analysis of the corpus of the study revealed that Youcef Ben Berkane Middle School learners face many problems in writing. In what follows, we try to show the findings of the present study and attempt to meet and answer the questions of the study. Hence, the results are shown mainly in tables and figures.

\section{Errors Identification \& Classification}

Figure 1 below summarizes the identified errors in the students' written compositions.

Figure 1 shows all the errors made by 62 middle school EFL learners studying at Youcef Ben Berkane Middle School in Akbou, Bejaia. The errors are identified and classified into eight types: Spelling, Punctuation, Tense, Sentence Fragments, Subject-Verb Disagreement, Articles and Prepositions, French Interference, and Others. 
Figure 1. Errors Identification \& Classification

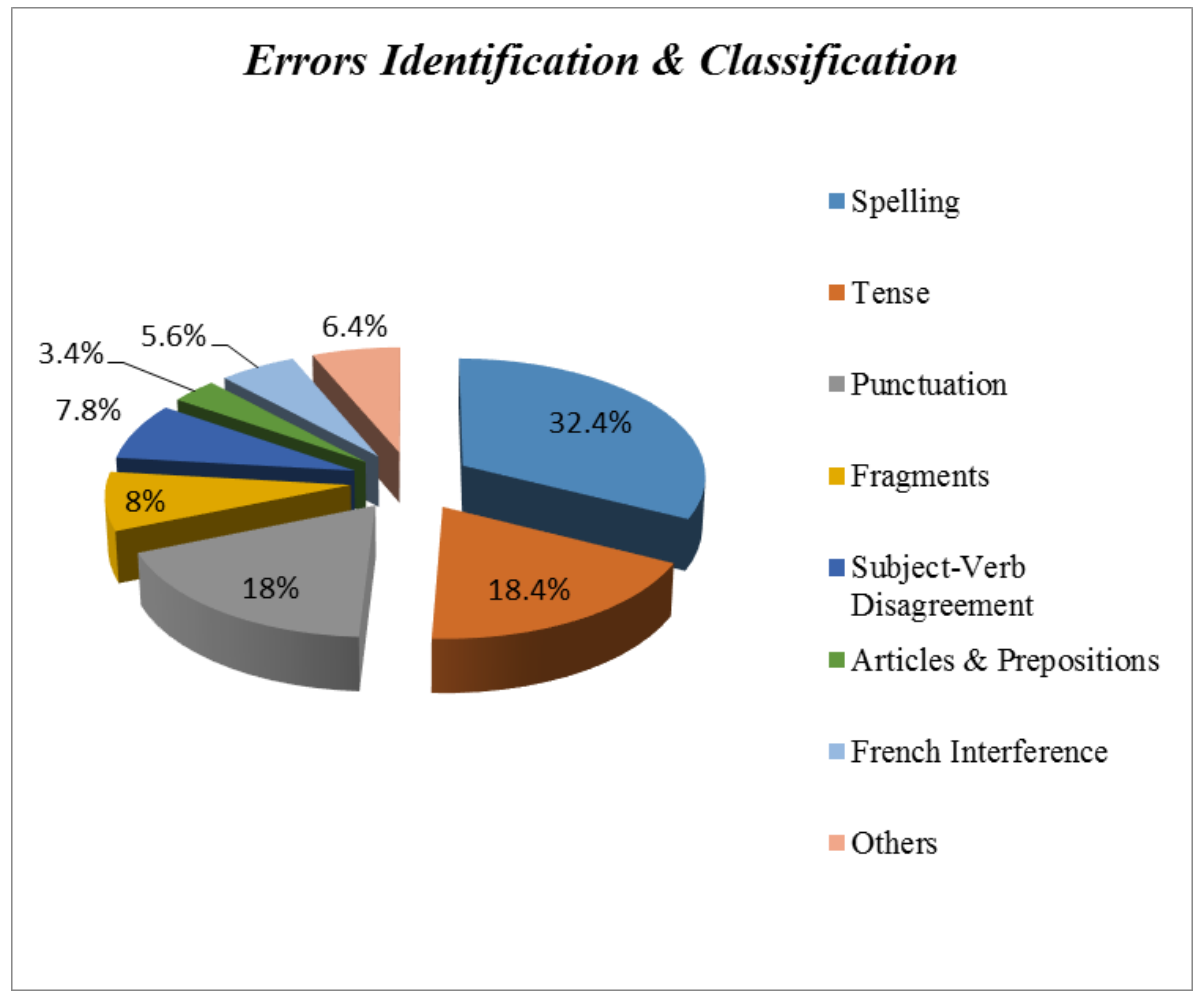

It is clear from the figure that $32,4 \%$ participants, which is the major score, make errors at the level of spelling. Then, it is followed by 'Tense' with $18,4 \%$. After that, come 'Punctuation' errors with $18 \%$. 'Sentence Fragment' comes in the fourth position with $8 \%$ of errors. In the fifth position, comes the 'Subject-Verb disagreement' with 7,8\%. The 'Other' category is ranked the sixth with $6,4 \%$. In the seventh position come the 'French Interference' errors with 5,6\%. In the last position, we have the errors related to 'Articles and Prepositions' with only 3, 4\%. It is noteworthy to acknowledge that this classification is similar to that of Hammar (2012).

\section{Errors Description \& Explanation}

The total number of errors made by middle school learners as a whole reaches 500 errors. These errors are classified into eight types related to language features including spelling, punctuation, tense, sentence fragment subject-verb disagreement, articles and prepositions, others and French interference. They are described and explained as follows: 
1 Spelling. The total number of spelling errors is 162 which represents the high score with $32,4 \%$ of the total number of errors. Table 1 below shows some examples of learners' spelling errors and their correction.

Table 1. A Sample of Spelling Errors

\begin{tabular}{|l|l|}
\hline \multicolumn{1}{|c|}{ Error Detection } & \multicolumn{1}{c|}{ Error Correction } \\
\hline $\begin{array}{l}\text { 1. I like eting a lot of shugure. } \\
\text { 2. I like whatching cartonse whith } \\
\text { my friend. }\end{array}$ & $\begin{array}{l}\text { 1. I like eating a lot of sugar. } \\
\text { 2. I like watching cartoons with } \\
\text { my friend. } \\
\text { 3. He becomes fayemes. }\end{array}$ \\
$\begin{array}{l}\text { 3. I don't new who it is. } \\
\begin{array}{l}\text { 5. He whent to the doctor and said } \\
\text { to him that he is faine and he can famous. } \\
\text { pley football again. }\end{array}\end{array}$ & $\begin{array}{l}\text { 5. He went to the doctor and said } \\
\text { play football again. }\end{array}$ \\
\hline
\end{tabular}

Table 1 presents a sample of spelling errors taken from the learners' pieces of writing. From a close sight to the examples we can understand that these spelling errors are due to the English pronunciation system. In other words, the disagreement that holds between the English spelling and pronunciation. Throughout learners' written papers, we have noticed that learners write as they hear as shown in all examples. This is also manifested through the omission of the silent letters like in example ' 4 '. Another spelling problem is that the majority of learners do not capitalize neither the first word in a sentence nor the name of places and persons.

1 Tense. The total number of tense errors is 92 errors which represents $18,4 \%$ of the total number of errors. Besides, tense errors come in the second position after spelling errors. Obviously, the learners have difficulties in choosing the appropriate tense. Moreover, when they know the appropriate tense they face problems in conjugating the verbs especially with regular and irregular verbs. 
Table 2. A Sample of Tense Errors

\begin{tabular}{|c|c|}
\hline Error Detection & Error Correction \\
\hline $\begin{array}{l}\text { 1. ... but the doctor telled him } \\
\text { 2. I heared a lot of cough } \\
\text { 3. the smoke growed up } \\
\text { 4. she has preparing her } \\
\text { homework } \\
\text { 5. He is happy because he cans } \\
\text { play football again. }\end{array}$ & $\begin{array}{l}\text { 1.....but the doctor told him. } \\
\text { 2. I heard a lot of cough. } \\
\text { 3. The smoke grew up. } \\
\text { 4. She is preparing her homework. } \\
\text { 5. He is happy because he can play } \\
\text { football again. }\end{array}$ \\
\hline
\end{tabular}

Table 2 shows the learners' errors related to tense use. After examining the learners' papers at the level of tenses, we find out a range of problems namely, the past marker 'ed' which is used erroneously with irregular verbs like in example 3. Moreover, the learners face problems related to tense formulation such as in example 4 in table 2 . Besides, and sometimes, the learners consider the auxiliaries as ordinary words where they conjugate them similarly with the verbs especially in the present simple, like in example 5 table 2. This might be related to learners' overgeneralization of rules. That is, the learners overgeneralize the use of 's' of the third person singular to all verbs (including the irregular verbs and modals).

1 Punctuation. The number of punctuation errors is 90 with a percentage of $18 \%$ which makes it the third type of errors that is highly frequent among middle school learners after the spelling and tense errors. Table 3 below illustrates some punctuation errors and their correction.

\section{Table 3. A Sample of Punctuation Errors}

\begin{tabular}{|l|l|}
\hline \multicolumn{1}{|c|}{ Error Detection } & \multicolumn{1}{|c|}{ Error Correction } \\
\hline 1. For example: I used to hate & $\begin{array}{l}\text { 1. For example, I used to hate } \\
\text { vegetables. }\end{array}$ \\
vegetables. & $\begin{array}{l}\text { 2. He is afraid, that he won't play afraid that he won't play } \\
\text { again. }\end{array}$ \\
again. I like watching cartoons, and & $\begin{array}{l}\text { 3. I like watching cartoons and } \\
\text { traveling, in the holidays. }\end{array}$ \\
$\begin{array}{l}\text { t. Suddenly a car comes ahead and the holidays. } \\
\text { hits her Suddenly, a car comes ahead } \\
\text { 5. His family is very happy, } \\
\text { because their child can play football } \\
\text { again }\end{array}$ & $\begin{array}{l}\text { and hits her. } \\
\text { their child can play football again. }\end{array}$ \\
\hline
\end{tabular}


Table 3 reveals that the pupils make punctuation errors at different levels. That is, either they do not use punctuation at all or they use it inappropriately. For example, they put the punctuation randomly, where it does not fit such as in the examples ' 2,3 , and 5 ' in table 3 . Besides, some of them write full sentences without any punctuation. Moreover, some learners put a specific punctuation mark that is not appropriate like in example ' 1 ' in table 3. Concerning the full stop, the majority of learners do not put it at the end of sentences.

1 Sentence Fragments. Sentence fragments represent $08 \%$ of the total number of errors. This type of error is ranked in the fourth position after spelling, tense, and punctuation. The below table illustrates some of them.

\section{Table 4. A Sample of Sentence Fragments}

\begin{tabular}{|l|l|}
\hline \multicolumn{1}{|c|}{ Sentence Fragments } & \multicolumn{1}{c|}{ Sentence Correction } \\
\hline $\begin{array}{l}\text { 1. Really it is fantastic animal } \\
\text { which. }\end{array}$ & $\begin{array}{l}\text { 1. Really it is a fantastic animal } \\
\text { which loves people. } \\
\text { 2. He plays football and he loves } \\
\text { 2. But love play handball. And he, } \\
\text { play football. }\end{array}$ \\
$\begin{array}{l}\text { 3. When he was training. } \\
\text { 4. After some days of his operation } \\
\text { in his leg. }\end{array}$ & $\begin{array}{l}\text { 3. When he was training, he broke } \\
\text { 4. After some days of his surgery, } \\
\text { he becomes better. }\end{array}$ \\
\hline
\end{tabular}

Table 4 illustrates some instances of sentence fragments which is a serious problem in the middle school pupils' written compositions. That is, they tend to write long sentences but incomplete. This phenomenon is manifested mainly in subordinate clauses such as in the examples ' 2,3 , and 4' where learners write the dependent clause and make a full stop. Hence, a clause that cannot stand alone causes a sentence fragment.

1 Subject-Verb Disagreement. This kind of errors represent 7,8\% of the total number of errors. The next table illustrates some cases of errors related to subject-verb disagreement. 
Table 5. A Sample of Subject-verb Agreement Errors

\begin{tabular}{|l|l|}
\hline \multicolumn{1}{|c|}{ Error Detection } & \multicolumn{1}{c|}{ Error Correction } \\
\hline 1. They was very sad. & 1. They were very sad. \\
2. He like to play football. & 2. He likes to play football. \\
3. He get up in the morning. & $\begin{array}{l}\text { 3. He gets up in the morning. } \\
\text { 4. He choose handball. }\end{array}$ \\
$\begin{array}{l}\text { 4. He chooses handball. } \\
\text { 5. His friends encourages him. }\end{array}$ & \\
\hline
\end{tabular}

Table 5 represents a set of examples related to subject-verb agreement errors made by middle school pupils. This category of errors represents 7, 8\%. A score that is not high but it represents a challenge for learners. Almost in each paper, we find at least one subject-verb agreement error. Learners either put a verb in singular form for plural subjects as in examples ' 1 and 5' or put the verb in the plural form for the singular subjects as in the examples ' 2,3 , and 4'. Again, this can be ascribed to the learners' overgeneralization of English rules. That is, the learners tend to overgeneralize the 'endingless' for all the pronouns (including the third person singular). So, this finding joins the findings of Kertous (2013).

1 Articles and Prepositions. The percentage of errors related to articles and prepositions is 3,4\%. This type represents the least category of English errors that are made by the middle school learners. These errors are manifested through either omitting the article or/and the preposition or putting inappropriate forms. Table 6 below, represents some examples of such errors.

Table 6 shows that the pupils face difficulties in choosing the appropriate prepositions. They are commonly using prepositions like 'to, of and in'. However, few learners use prepositions like 'from, on, at'. Moreover, some learners use the prepositions inappropriately as it is illustrated in examples ' 2 , 3,4 , and 6'. As far as the articles are concerned, we notice that the learners use the three types of articles ' $a / a n$, the, and zero article' but there are some cases where learners do not use articles at all, as it is illustrated in examples ' 1 and 5'. 
Table 6. A Sample of Articles and Prepositions Related Errors

\begin{tabular}{|c|c|c|}
\hline \multirow[t]{2}{*}{ Error Detection } & \multicolumn{2}{|c|}{ Error Correction } \\
\hline & Article & Preposition \\
\hline $\begin{array}{l}\text { 1. He becomes } \times \text { best } \\
\text { footballer. }\end{array}$ & $\begin{array}{l}\text { 1. He becomes the } \\
\text { best footballer. }\end{array}$ & 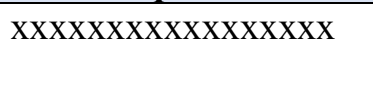 \\
\hline $\begin{array}{l}\text { 2. When she comes } \\
\text { back to school. }\end{array}$ & 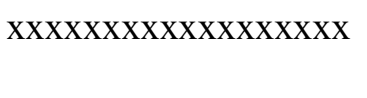 & $\begin{array}{l}\text { 2. When she comes } \\
\text { back from school. }\end{array}$ \\
\hline $\begin{array}{l}\text { 3. He comes back at } \\
\text { his team. }\end{array}$ & 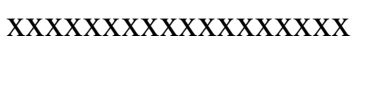 & $\begin{array}{l}\text { 3. He comes back to } \\
\text { his team. }\end{array}$ \\
\hline $\begin{array}{l}\text { 4. In the end, he } \\
\text { comes back. }\end{array}$ & XXXXXXXXXXXXXXXXXX & $\begin{array}{l}\text { 4. At the end, he comes } \\
\text { back. }\end{array}$ \\
\hline $\begin{array}{l}\text { 5. A woman was } \\
\text { going to call } \times \text { police. }\end{array}$ & $\begin{array}{l}\text { 5. A woman was going } \\
\text { to call the police. }\end{array}$ & 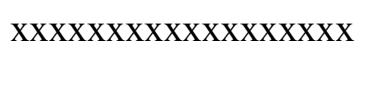 \\
\hline $\begin{array}{l}\text { 6. The best footballer } \\
\text { of the world. }\end{array}$ & 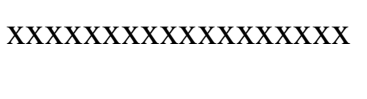 & $\begin{array}{l}\text { 6-the best footballer in } \\
\text { the world. }\end{array}$ \\
\hline
\end{tabular}

1 French Interference. This category represents 5, 6\% of the total percentage of errors. It is ranked before the last. Hence, French interference errors refer to errors resulted from negative transfer from the French language. They are categorized into two main types namely lexical interference and orthographic interference, as shown in figure 2 below.

Figure 2. French Interference Errors' Classification

\section{French Interference Errors' Classification}
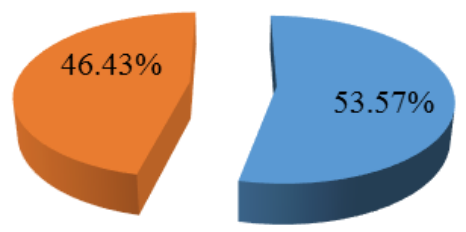
- Lexical Interference (Full French Words)
- Orthographic Interference (Partial French Spelling)

Accordingly, Table 7 represents some examples of French interference errors. 
Table 7. A Sample of French Interference Errors

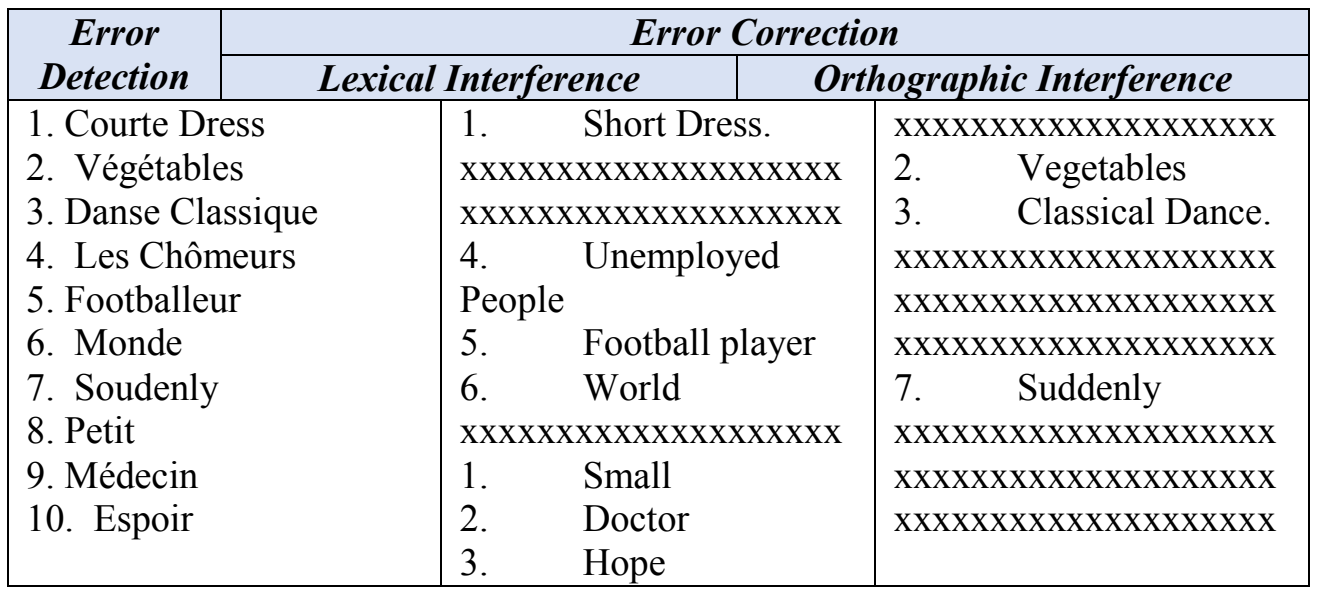

Table 7 shows some examples of French interference errors. Even though they do not represent a great number, still they are a challenge for middle school learners. From this table, we notice that the French language influences negatively learners' production in English; this is manifested mainly in two areas, namely lexical interference and orthographic interference. In the former, learners take exactly the French word when they ignore it in the English language. This is illustrated in examples ' $1,4,5,6,8,9$, and 10'. Thus, this might be due to learners' lack of the English vocabulary. However, orthographic interference takes place when a word exists in both languages with a slight difference in spelling such as in examples ' 2,3 , and 7'.

8 Others. This category represents $6.4 \%$ of the total percentage of errors. A score that is higher than the errors related to articles \& prepositions and French interference. This category of errors consists of ambiguous words due to the unintelligible handwriting, repeated words, and misplaced words. These errors are highlighted by using a circle or a question mark during the analysis process.

\section{Errors' Sources}

After classifying all the identified errors into the eight possible categories namely spelling, punctuation, tense, sentence fragments, subject-verb disagreement, articles \& prepositions, French interference, and others. Now, we attempt to categorize them according to their sources. Figure 3 below shows the results. 
Figure 3. Sources of Errors

\section{Sources of Errors}

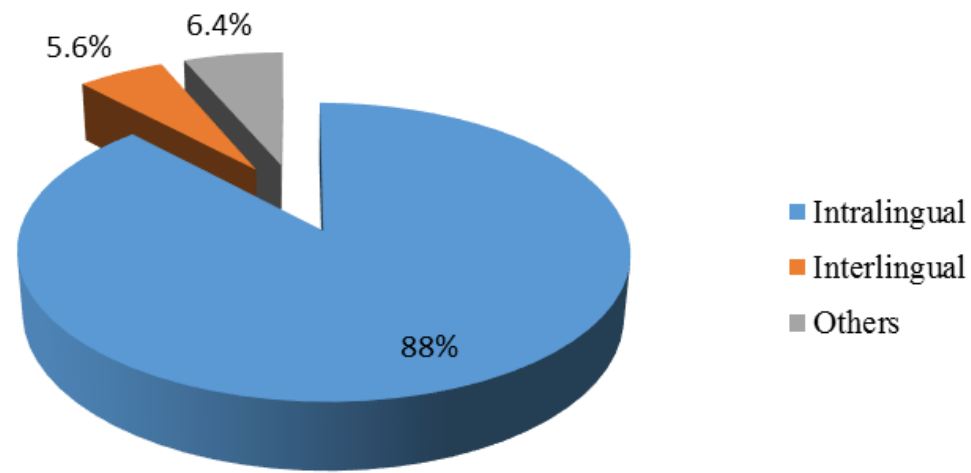

Figure 3 shows the distribution of errors according to their sources. Errors are unavoidable in EFL learning. Thus, learners tend to make a range of errors at different language levels. According to figure 3, $88 \%$ of pupils' errors are intralingual. That is to say, errors that are resulted from incomplete knowledge of the rules of the target language; whereas, 5, 6\% of pupils' errors are resulted from interlingual interference. It is related to the errors that are resulted from French language negative transfer.

\section{CONCLUSIONS \& PEDAGOGICAL IMPLICATIONS}

The findings of the present study show that Youcef Ben Berkane Middle School learners make a lot of intralingual and interlingual errors in their written compositions. To be precise, they make errors mainly, and with high frequency, at the levels of spelling, tense, punctuation, sentence fragment, and subject-verb disagreement. Moreover, the main sources behind middle school learners' errors in writing are intralingual source with high percentage and interlingual source with a low percentage. Hence, the findings of the present study answered the study questions and confirmed the study hypothesis.

Based on the findings of the present study, a number of pedagogical implications can be addressed to both teachers and pupils:

As it is shown in our results, spelling errors are the most frequent type. Thus, teachers should give a special care to their learners' spelling through raising learners' awareness that there is no correspondence between how English words are pronounced and how they are spelt. Moreover, confusions should be highlighted by the teacher in areas where the similarities between French and English spelling are great and are expected to cause problems to learners of English. 
VOLUME 9

As far as handwriting is concerned, it is of great importance because it may affect the readers' understanding of the written text. Moreover, badlyformed words will be perceived by the reader as carelessness from the writer. In fact, teachers should develop learners' handwriting especially for young learners through special writing workshops. Besides, teachers have to engage learners in practicing letters formation and provide them with a written model that they should imitate. Accordingly, much importance should be given to the writing skill since it is one of the basic language production skills. Teachers should devote much time to the practice of this vital skill and engage learners in authentic situations.

As far as the spelling resemblance that exists between French and English, EFL teachers should underline and stress on the similarities between the two languages. That is to say, they should highlight the English words that have a quite similar spelling in French. Hence, a limit should be put between the two words in order to narrow the interlingual errors.

\section{LIMITATIONS OF THE STUDY}

The present study has the following limitations: first, the participants' age is the main limitation of the present study. That is to say, working with young learners is not an easy task and especially we are not familiar to them. Hence, they are less willing to cooperate. Second, the variable of gender is not considered in this study. Third, the sample of the study is limited to EFL learners of Youcef Ben Barkene Middle School. Thus, the findings cannot be generalized to other schools.

\section{REFERENCES}

Abdul Haq, F. (1982). An Analysis of Syntactic Errors in the Composition of Jordanian Secondary Students (Unpublished MA Thesis). Yarmouk University, Jordan.

Adway, A.E. (2013). The Study of the English Article System Errors Made by Secondary School Students in the United Arab Emirates (Unpublished MA Thesis). Dubai University, United Arab Emirates.

Al-Bayati, W. (2013). Errors Made by Iraqi EFL Undergraduates in the Use of Prepositions. Philology and Cultural Studies, 6 (55), 41-55.

Al-Hazmi, S. (2006).Writing Reflection: Perceptions of Arab EFL Learners. South Asian Language Review, 16 (2), 36-52.

Al-Khatib, H. (2013). Can Universal Linguistic Fundamentals Contribute to the Interpretation of EFL Learning?. European Scientific Journal, 9 (35), 28-43.

Al-Khuweileh, A. \& Al-Shoumali, A. (2000).Writing Errors: A study of the Writing Ability of Arab Learners of Academic English and Arabic at University. Journal of Language, Culture and Curriculum, 13 (2), 174-183. 
Al-Samadani, H.A. (2010). The Relationship between Saudi EFL Students' Writing Competence, L1 Writing Proficiency, and Self-regulation. European Journal of Social Sciences, 16 (1), 53-63.

Boulekroune, A. (2014). Investigating the Impact of Collaborative Writing on the Students' Grammatical Errors in their Writing Compositions (Unpublished MA Thesis). Bejaia University, Algeria.

Byrne, D. (1988). Teaching Writing Skills. London: Longman.

Corder, S.P. (1973). Introducing Applied Linguistics. Harmondsworth: Penguin.

Hammar, M. (2012). Diagnosis of Some Contributory Factors to Some Students' Errors in Written English (Unpublished MA Thesis). Bejaia University, Algeria.

Heydari, P., \& Bagheri, M. (2012). Error Analysis: Sources of L2 Learners' Errors. Theory and Practice in Language Studies, 2, 8, 1583-1589.

James, C. (1998). Errors in Language Learning and Use: Exploring Error Analysis. Malaysia: Addison Wesley Longman.

Javid, C. Z., \& Umer, M. (2014). Saudi EFL Learners' Writing Problems: A Move Towards Solution. Proceeding of the Global Summit on Education .Retrieved on 4-5 March 2014, Kuala Lumpur, Malaysia.

Kertous, Z. (2013). Investigating the Factors Behind Foreign Language Learners' Grammatical Errors in Writing Skill: the Case of Second Year LMD Students of English (Unpublished MA Thesis). Bejaia University, Algeria.

Kitzhaber, A. R. (1963). Themes, Theories, and Therapy: The Teaching of Writing in College. New York: McGraw-Hill Book Company.

Mammeri, S. (2015). A Morphosyntactic Study of EFL Students' Written Compositions: A Corpus Based Analysis. Arab World English Journal Proceedings of Bejaia University International Conference on Innovations in Teaching and Learning English: New Methods \& Approaches, 112-126.

Ouskourt, M. (2008). Developing Efficient Writing Strategies Through The Process Approach and Teacher's Feedback (Unpublished Doctoral Dissertation). Conatantine University, Algeria.

Richards, J.C. (1970, March). A Non-Contrastive Approach to Error Analysis. Paper presented at the TESOL Convention, San Francisco.

Richards, J.C. (1974). Error Analysis. Perspectives on Second Language Acquisition. London: Longman

Sawalmeh, M. (2013). Error Analysis of Written English Essays: The Case of Students Of The Preparatory Year Program In Saudi Arabia. Journal of English specific purposes world 14(40), 1-17.

Sridhar, S.N. (1975). Contrastive Analysis, Error Analysis and Interlanguage: Three Phases of One Goal? Studies in Language Learning, 1.

Taghavi, M. (2012). Error Analysis In Composition of Iranian Lower Intermediate Students (Unpublished MA Thesis). Guilan University, Iran.

Time4Writing. (2015). Common Problems in Middle School Writing. Retrieved from http://www.time4writing.com/writing-resources/writing-problems-middle-school/

Yang, W. (2010). A Tentative Analysis of Errors in Language Learning and Use. Journal of Language Teaching and Research, 1 (3), 266-268.

Zawahreh, F.A. (2012). Applied Error Analysis of Written Production of English Essays of Tenth Grade Students in Ajloun Schools, Jordan. International Journal of Learning \& Development, 2 (2), 63-69. 